Самолюк Н. М. ${ }^{[1 ; ~ O R C I D ~ I D: ~ 0000-0001-8693-8558], ~}$ к.е.н., доцент

${ }^{1}$ Національний університет водного господарства та природокористування, м. Рівне

\title{
ОСОБЛИВОСТІ РОЗПОДІЛУ ДОХОДІВ СТЕЙКХОЛДЕРІВ СОЦІАЛЬНО-ТРУДОВОЇ СФЕРИ
}

В статті розглянуто особливості функціонального розподілу доходів в розрізі країн Європейського Союзу та України; проаналізовано тенденцію розподілу доданої вартості між факторами виробництва за видами економічної діяльності; досліджено структуру частки доходу, що належить фактору «праця» за критерієм законодавчої гарантованості чи добровільності.

Ключові слова: доходи; додана вартість; розподіл доходів; фактори виробництва; функціональний розподіл доходів; витрати на робочу силу.

Постановка проблеми. Справедливий розподіл доходів між факторами виробництва лежить в основі соціально-економічного розвитку держави, адже стимулює ефективне ведення трудової та бізнес-діяльності. Відтак, дослідження функціонального розподілу доходів дозволяє говорити про ефективність соціальної політики держави та розробляти напрямки економічного розвитку. На жаль, в Україні в умовах високого рівня безробіття, низького рівня дієвості профспілкового руху та соціальної відповідальності роботодавців постає проблема досягнення справедливості розподілу доходів. Тому незважаючи на значну кількість наукових праць у цьому напрямку, актуальність дослідження розподілу доданої вартості між факторами «капітал» та «праця» не викликає сумніву.

Аналіз останніх досліджень. Вперше питання розподілу доходів в рамках економічної теорії підняв Ф. Кене у своїй праці «Економічна таблиця» [1]. Представники класичної економічної школи (А. Сміт, Д. Рікардо) вважали, що всі мають частку в національному доході, тож добробут кожного залежить від добробуту суспільства [2; 3]. Відповідно до вчення класиків, у розподілі доходів приймають участь три класи (власники капіталу, землі та праці), які отримують три види доходів, а саме - прибуток, земельну ренту та заробітну плату. При цьому, класики відмічали, що «перекоси» у розподілі доходів можуть стати перешкодою для економічного зростання. Згодом теорія розподілу доходів була розвинена в працях Дж. М. Кейнса, який розмежував дохід підприємця i доходи населення та запропонував концепцію державної політики регулювання доходів, в 
основі якої лежить управління попитом [4]. Однак монетаристи, зокрема М.Фрідмен, в своїх працях виступали за обмежене державне регулювання доходів та підтримували ідею неприйняття соціальних програм уряду, направлених на підтримку малозабезпечених верств населення [5].

Питанням диференціації доходів, зокрема обґрунтуванню науково-методологічних основ дослідження диференціації доходів, присвячені праці таких зарубіжні вчених, як М.Лоренца [6], Х. Дальтона [7], А. Аткінсона [8], Ф. Коуела [9], С. Іцхакі та Р. Лермана [10] та ін.

Значний внесок у розробку проблеми розподілу доходів здійснили вітчизняні науковці. Найчастіше розглядають окремі аспекти формування доходів, насамперед домогосподарств, менше аналізують проблеми факторного розподілу доходів, зокрема Мандибура В. у своїх працях приділяє увагу формуванню реальних доходів населення [11]; Пономаренко В., Кизима М., Узунов Ф. дослідженню рівня життя і реальних доходів [12]; ЮрчикГ. оцінюванню диференціації доходів населення з урахуванням тіньової компоненти [13]; Дучинська Н. - ринковій ефективності розподілу доходів [14]. Окрім побудови факторних моделей розподілу доходів, предметом досліджень В. Семенова та А. Гвелесіані $€$ аксіоматичне представлення декомпозиції нерівності індексів Аткінсона, Джині, Шеплі за демографічними групами та за джерелами доходів [15; 16]. Водночас чимало питань у теорії розподілу доданої вартості залишаються невирішеними, зокрема питання балансу між ефективністю та справедливістю розподілу, а також роль держави в цьому процесі.

Постановка завдання. Враховуючи зазначене, метою цієї роботи є дослідження тенденцій розподілу доданої вартості (далі ДВ) між факторами виробництва в галузевому та регіональному розрізі, а також структури частки доходу, що належить фактору «праця» за критерієм законодавчої гарантованості.

Виклад основного матеріалу. Механізм розподілу доданої вартості варто розглядати у розрізі ії складових. У розподілі ДВ приймають участь наймані працівники, власники/інвестори підприємств та держава. Відтак, працівники отримують свою частку у вигляді заробітної плати, держава - як відрахування на соціальне страхування працівників, а інвестори та власники - у вигляді дивідендів, ренти та розподіленого прибутку. Крім того, частина ДВ може направлятися для рекапіталізації виробництва (фонд розвитку виробництва) або у резервний фонд (акумулює резерв коштів підприємства на випадок настання непередбачуваних несприятливих обставин) [17]. 
У макроекономічному аналізі та міжнародних порівняннях використовуються показники «частка оплати праці» та «часка валового прибутку» у валовому внутрішньому продукті (далі - ВВП) або у доданій вартості (далі - ВДВ). Дослідження функціонального розподілу ВДВ в країнах ЄС між зазначеними факторами свідчить про досить пропорційний її розподіл - 44,4\% припадає на заробітну плату, а 46,1\% - на прибуток (рис. 1). Водночас поміж країн ЄС існує значна диференціація у відносних показниках розподілу ДВ між факторами виробництва. Так, за даними 2016 р., найбільша частка прибутку в доданій вартості спостерігається в Словаччині (75\%), Румунії (70\%), Греції (69\%), Польщі, Чехії (близько 61\%). При цьому в Данії, Латвії, Люксембурзі, Ірландії частка заробітної плати в структурі ДВ переважає та варіює в межах 60-72\%. Таким чином, в ЄС не існує єдиної політики щодо факторного розподілу доданої вартості [18].

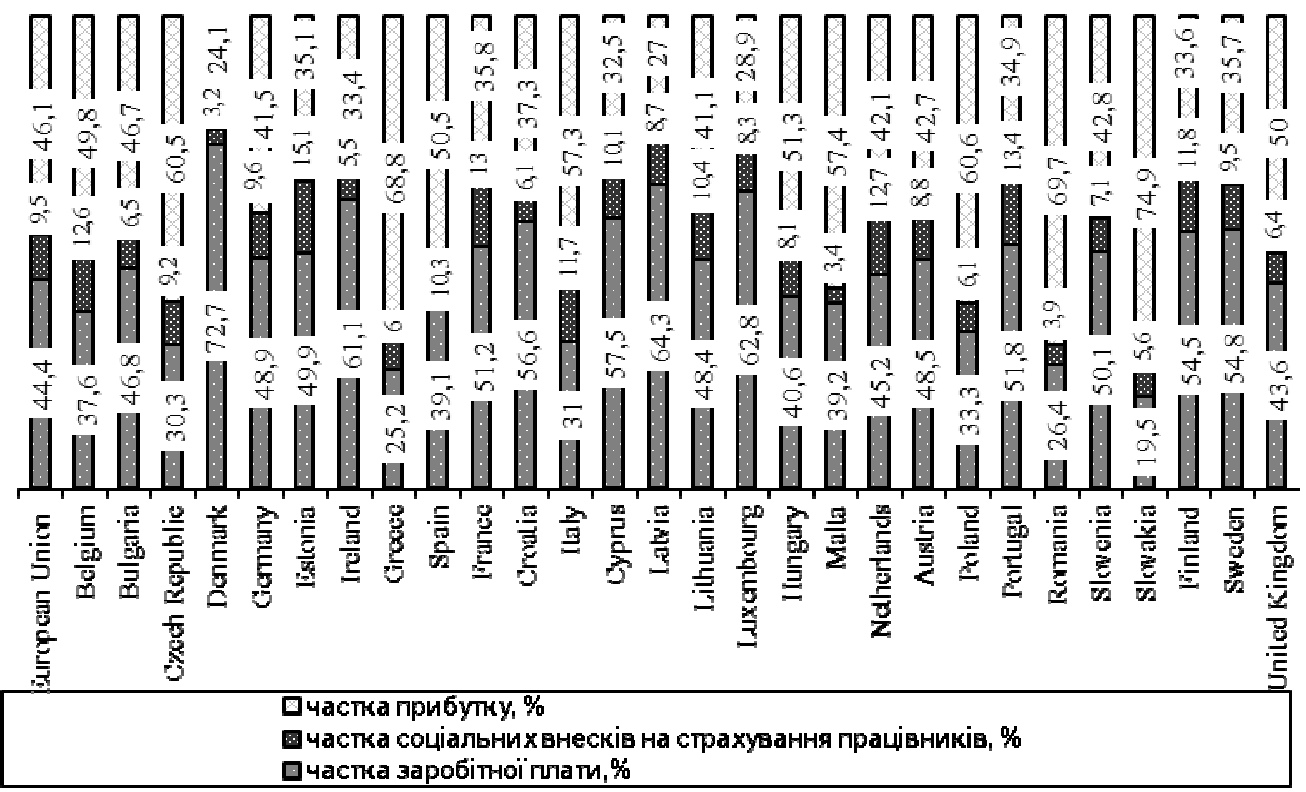

Рис. 1. Розподіл валової доданої вартості в країнах ЄС (2016р.) [18]

Впродовж 2014-2019 років динаміка частки заробітної плати у ВДВ України не мала стійкої тенденції та коливалася в межах 36,6$46,3 \%$. При цьому, частка прибутку також була нестабільною i змінювалася від 40,8\% до 47,9\% (рис. 2). 


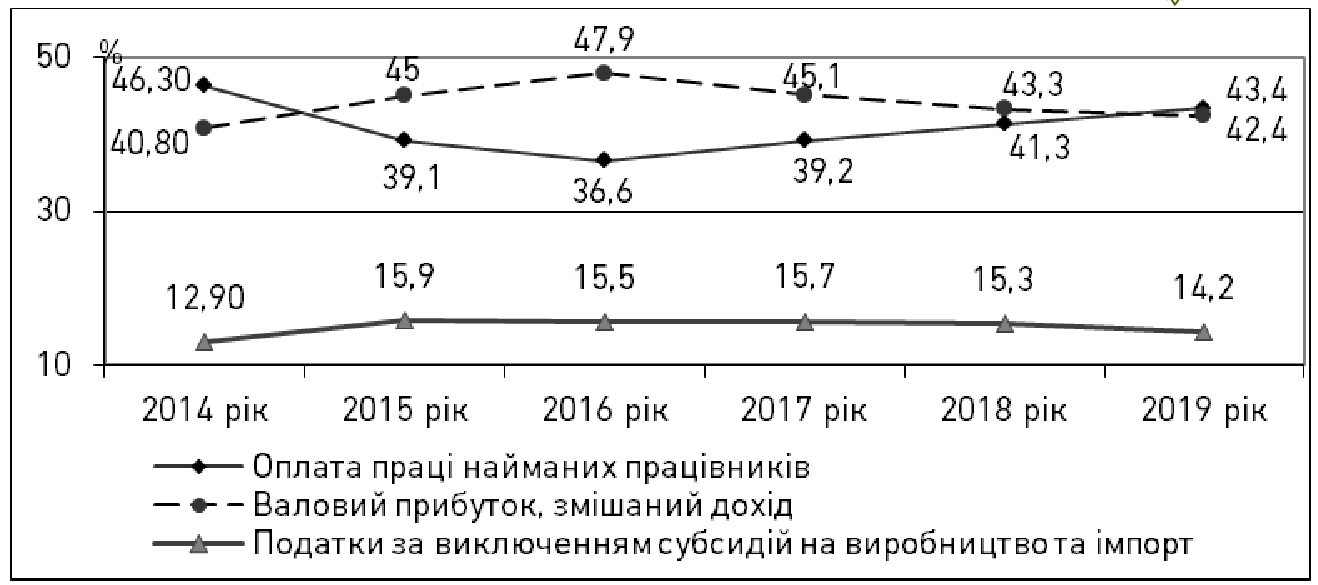

Рис. 2. Динаміка частки «праці» та «капіталу» у ВДВ України у 2014-2019 рр. Джерело: побудовано автором на основі [19]

Загалом частка суспільного продукту належна фактору «праця» в Україні відповідає середньому показнику по країнах ЄС. Однак, частка зарплати у ВВП за видами економічної діяльності відрізняється від середньостатистичної на десятки відсотків (рис. 3). Так, у будівництві впродовж 2014-2019 років вона була більшою за середню по Україні і коливалася від 47,2 до 56,9\%, а у сільському господарстві - удвічі меншою за середню і становила 14,6-22,6\%.

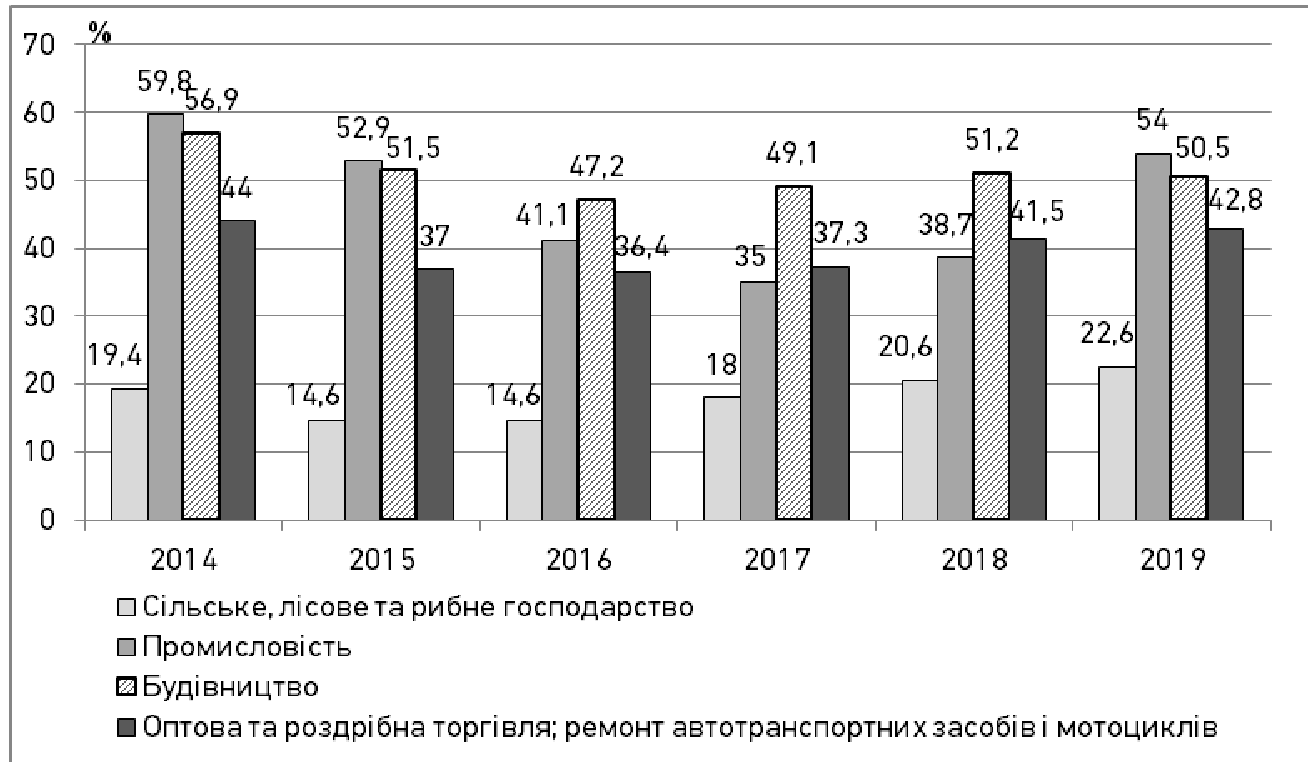

Рис. 3. Частка зарплати у ВДВ за основними видами діяльності у 2014-2019 pp.

Джерело: побудовано автором на основі [19]

Варто відмітити, що у зв'язку з освоєнням в Україні 
міжнародних стандартів і ринкової термінології з'явились нові терміни і поняття, які ідентифікують зарплату та інші витрати на працівників, в тому числі близькі за змістом поняття «витрати на робочу силу» і «витрати на персонал», проте динаміка загальних витрат на персонал не відображає реальний стан речей у розподільчих відносинах, для цього краще використовувати показник «витрати на одного працівника». Тому, скориставшись даними Державної служби статистики України та даними Статистичної служби Європейського Союзу, проаналізуємо динаміку витрат на одного працівника за одну годину в розрізі різних країни.

Як видно з рис. 4, в 2014 р. середні витрати на одного працівника в Україні становили всього 2,2 євро/год, що в 11,2 разів менше ніж в середньому по країнах ЄC, де вони рівні 24,6 євро/год. На жаль, у 2018 році ситуація змінилася лише в гіршу сторону годині витрати на одного працівника в Україні у 11,9 разів менші за аналогічні витрати у ЄС. При цьому, у 2018 році годині витрати на українського працівника менші в порівнянні з Норвегією в 22 рази, 3 Польщею - в 4,4 рази, і навіть в порівнянні з Румунією - в 3 рази.

Тож, як бачимо, в економічно розвинутих країнах Європи праця для роботодавця коштує недешево. Величина основних і додаткових витрат на персонал у розрахунку на одного працівника за рік еквівалентна вартості трьох нових легкових автомобілів середнього класу.

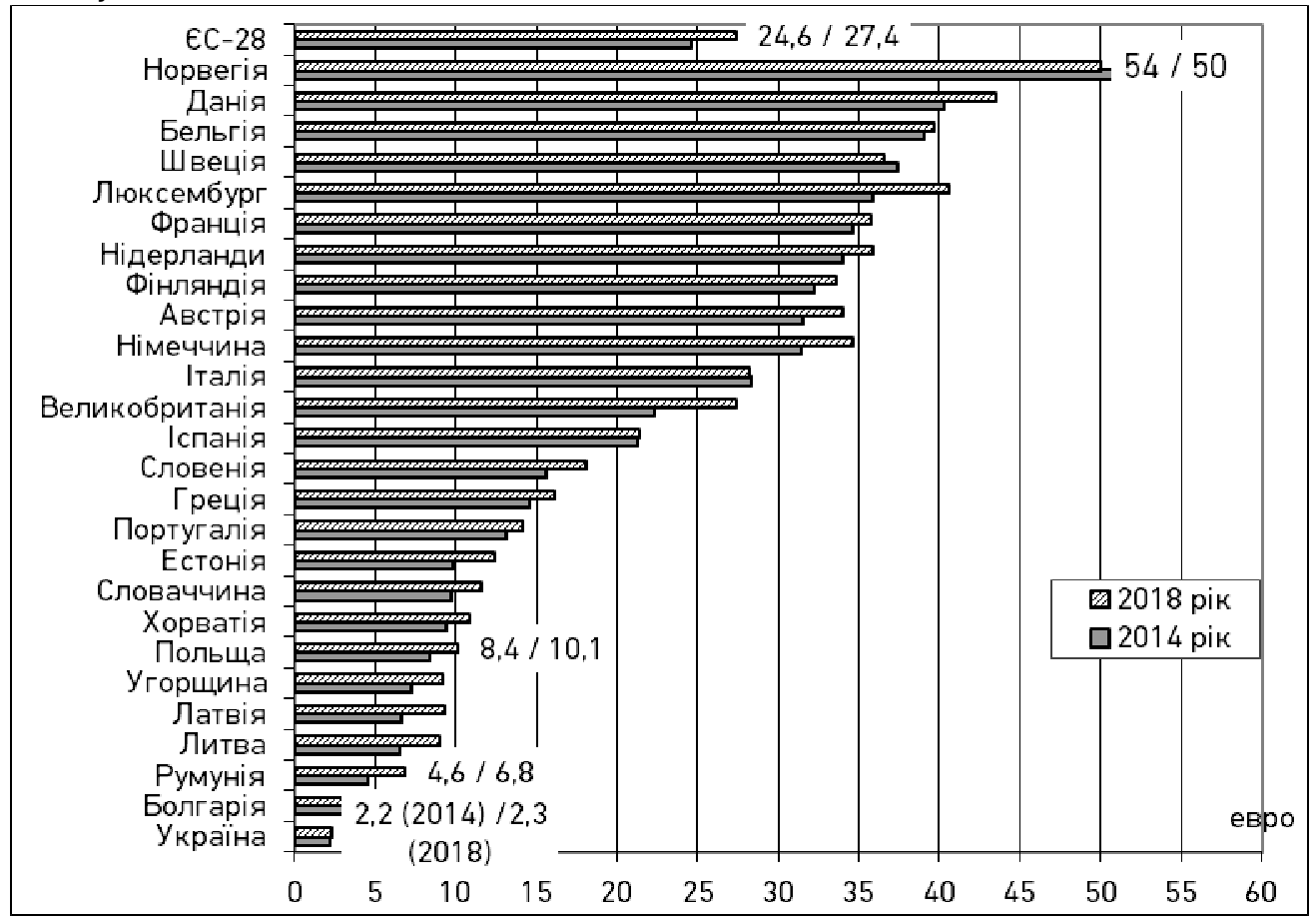

Рис. 4. Витрати (на 1 працівника за годину) у 2014 та 2018 роках, євро Джерело: побудовано автором на основі [19; 20] 
У світовій практиці витрати на робочу силу прийнято поділяти на дві групи елементів: винагороду за виконану роботу і додаткові витрати. Склад, структура, величина додаткових витрат визначається за різними критеріями, залежно від яких вони i класифікуються. Витрати першої групи, залежно від їх зв'язку 3 результатами праці, поділяються на позазарплатні витрати та витрати на оплату праці [21].

До другої групи належать витрати, що належать до оплати праці й спрямовуються на:

- відтворення робочої сили (харчування, напої, паливо та інші натуральні виплати; забезпечення працівників житлом);

- соціальний захист;

- професійне навчання;

- культурно-побутове обслуговування [21].

В структурі витрат на робочу силу в країнах ЄС та Україні частка витрат на оплату праці у 2018 році знаходиться у досить широкому діапазоні, а саме: 93,9\% на оплату праці припадає на Мальті і лише 67,4\% - у Франції (рис. 5). Відповідно і часка відрахувань на соціальні заходи в європейських країнах суттєво різниться і коливається від 6,1\% до 32,3\% від загальних витрат на робочу силу.

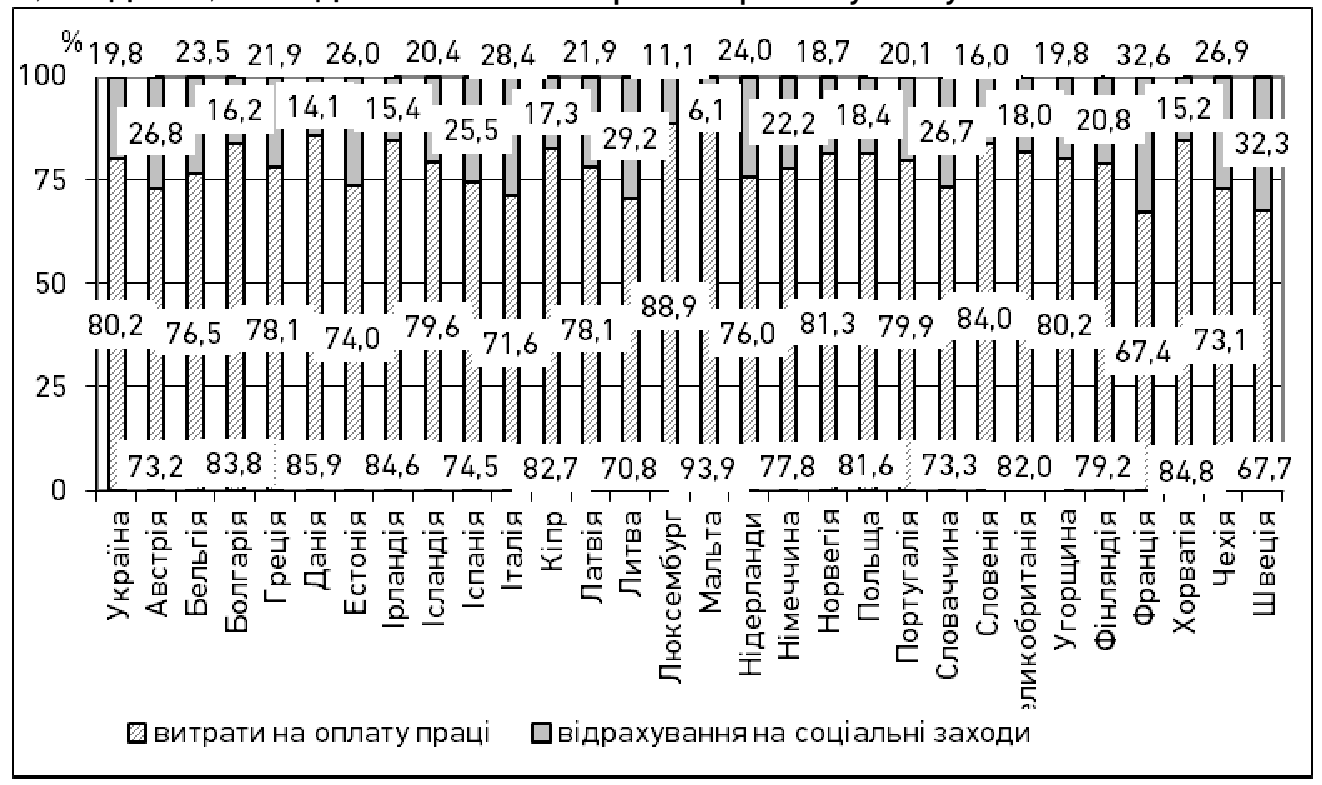

Рис. 5. Структура витрат на робочу силу в Україні і країнах ЄС у 2018 р. Джерело: побудовано автором на основі [19; 20] 
Також усю сукупність витрат на утримання найманих працівників, відповідно до Міжнародної стандартної класифікації витрат на робочу силу та Інструкції по визначенню вартості робочої

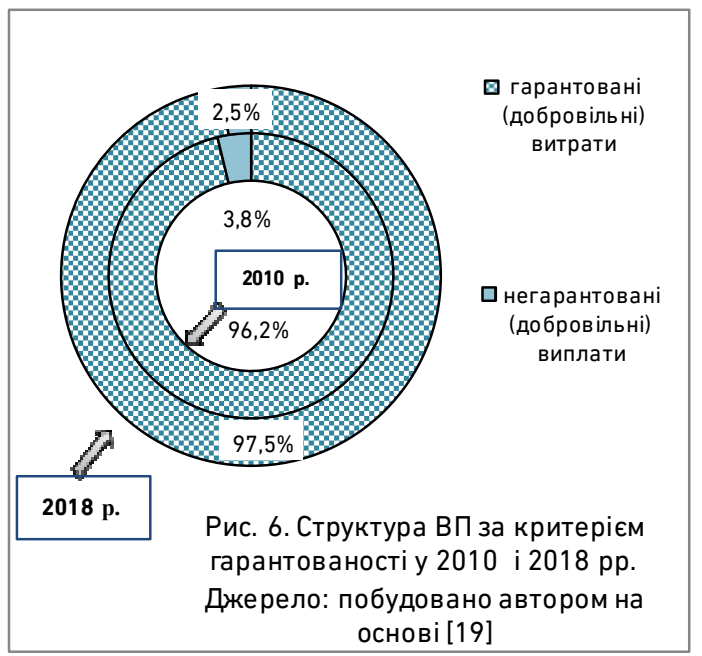
сили, включає 10 груп витрат, котрі за критерієм законодавчої гарантованості, можна поділити на дві групи:

1) гарантовані (добровільні) витрати (пряма оплата праці; оплата за невідпрацьований час; премії та нерегулярні виплати; заробітна плата у натуральній формі; соціальне забезпечення працівників (в т.ч. податки);

2) негарантовані (добровільні) виплати (оплата житла працівників; професійне навчання; культурно-побутове обслуговування та інші витрати).

Умовне групування витрат на персонал за критерієм їх гарантованості дозволило провести відповідний статистичний аналіз їх структури (рис. 6). Зокрема, частка законодавчо гарантованими витрат в Україні $€$ достатньо високою і має стійку тенденцію до зростання. Водночас частка негарантованих витрати $є$ надзвичайно низькою і має негативну тенденцію до зменшення, що свідчить про надзвичайно низьку соціальну відповідальність бізнесу. В Україні також наявні додаткові та соціальні виплати, передбачені державою. Однак, коло найманих працівників, на які вони поширюються, $€$ обмеженим. Наприклад, у зв'язку із шкідливими умовами праці на деяких підприємствах, окремих видів економічної діяльності, працівникам надаються путівки на лікування та відпочинок і т.д.

Висновки. Отже, проаналізувавши тенденції розподілу доходів між учасниками соціально-трудових відносин виявлено, що частка суспільного продукту належна найманим працівникам в Україні більш-менш відповідає середньому показнику по країнах ЄС. Однак, оскільки динаміка загальних витрат спрямованих на утримання найманих працівників не відображає реальний стан речей у розподільчих відносинах, тому для цього більш доцільно використовувати показник «витрати на одного працівника». Результати аналізу показали, що середні витрати на одного працівника в Україні значно відстають від аналогічних витрати в країнах ЄС, і щороку цей розрив зростає. Крім того, виявлено, що частка законодавчо гарантованими витрат, які власник зобов'язаний 
здійснювати на користь своїх працівників, в Україні $€$ достатньо високою і має стійку тенденцію до зростання. При цьому ті витрати, що здійснюються на добровільній основі і не врегульовуються державою, в Україні, на відміну від країн ЄС майже не здійснюються. Звісно, що така ситуація характеризує соціальну відповідальність вітчизняного бізнесу не з найкращої боку та не сприяє лояльності персоналу, а навпаки, призводить до плинності кадрів та підвищення міграційних устремлінь працівників.

1. Quesnay F. The 'Third Edition' of the Tableau Economique: Facsimile Reproduction and English Translation. In Green Accounting. Routledge. 2018. P. 3-29. 2. Ricardo D. On the Principles of Political Economy and Taxation (1821). Kessinger Publishing. 2009. 3. Smith $A$. An inquiry into the nature and causes of the wealth of nations. London: printed for W. Strahan; and T. Cadell. Volume One. 1776. 4. Keynes J. M. The general theory of employment, interest, and money. Macmillan Cambridge University Press. 1936. 5. Friedman M. A theoretical framework for monetary analysis. Journal of Political Economy. 1970. 78(2). P. 193-238. 6. Lorenz M. O. Methods of Measuring the Concentration of Wealth. Publications of the American Statistical Association. 9(70) (Jun., 1905). P. 209-219. 7. Dalton H. The Measurement of the Inequality of Income. The Economic Journal. 1920. 30 (119). P. 348-361. 8. Atkinson A.B. On the Measurement of Inequality. Journal of Economic Theory. 1970. № 2. P. 244-263. 9. Cowell F. A. On the Structure of Additive Inequality Measures. Review of Economic Studies. 1980. № 47. P. 521-531. 10. Yitzhaki S. and Lerman R. Income Inequality Effects by Income Source: a New Approach and Applications to the United States. The Review of Income and Wealth. 1991. № 37. P. 313-329. 11. Мандибура В. О. Рівень життя населення України та проблеми реформування механізмів його регулювання. К. : Парлам. вид-во, 1998. 223 с. 12. Пономаренко В. С., Кизим М. О., Узунов Ф. В. Рівень і якість життя населення України : монографія. Х. : ІНЖЕК, 2003. 226 с. 13. Юрчик Г. М., Самолюк Н.М. Оцінювання диференціації доходів населення України 3 урахуванням їх тіньової компоненти. Демографія та соціальна економіка. 2016. № 3 (28). С. 133-145. 14. Дучинська Н. І. Розподіл доходів: ринкова ефективність та соціальна справедливість. Науковий вісник Міжнародного гуманітарного університету. Сер. Економіка і менеджмент. 2015. № 14. С. 254-257. 15. Семенов В. В. Економіко-статистичні моделі та методи дослідження соціальних процесів: нерівність, бідність, поляризація : монографія: в 2 т. / відп. ред. Новіков В. М. Полтава : РВВПУСКУ, 2008. Т. 1. Нерівність. 237 с. 16. Гвелесіані А.Г. Оцінка структури грошових доходів населення України методом декомпозиції коефіцієнта Джині. Демографія та соціальна економіка. 2009. № 2. С. 153-161. 17. Юрчик Г. М., СамолюкН. М. Теоретичні аспекти формування, розподілу та перерозподілу доданої вартості. Економіка та суспільство. 2018. № 14. С. 49-59. URL: http://economyandsociety.in.ua (дата звернення: 20.09.2020). 18. Bilan Y., Mishchuk H., Samoliuk N., Yurchyk H. Impact of income distribution on social and economic wellbeing of the state. Sustainability. 2020. 12(1). P. 429. DOI: https://doi.org/10.3390/su12010429. 19. Статистичні дані Державної служби статистики України. Витрати на робочу силу : статистичні збірники за 2010, 2014 та 2018 роки. URL: http://www.ukrstat.gov.ua (дата звернення: 20.09.2020). 20. Статистичні дані Євростат. Структура витрат на робочу силу. URL: http://epp.eurostat.ec.europa.eu (дата звернення: 20.09.2020). 21.Гуменюк В. Я., Самолюк Н. М. Управління витратами на персонал : монографія. Рівне : НУВГП, 2012. 158 c. 
Серія «Економічні науки»

Випуск 4(92) 2020 р.

\section{REFERENCES:}

1. Quesnay F. The 'Third Edition' of the Tableau Economique: Facsimile Reproduction and English Translation. In Green Accounting. Routledge. 2018. P. 3-29. 2. Ricardo D. On the Principles of Political Economy and Taxation (1821). Kessinger Publishing. 2009. 3. Smith A. An inquiry into the nature and causes of the wealth of nations. London : printed for W. Strahan; and T. Cadell. Volume One. 1776. 4. Keynes J. M. The general theory of employment, interest, and money. Macmillan Cambridge University Press. 1936. 5. Friedman M. A theoretical framework for monetary analysis. Journal of Political Economy. 1970. 78(2). P. 193-238. 6. Lorenz M. O. Methods of Measuring the Concentration of Wealth. Publications of the American Statistical Association. 9(70) (Jun., 1905). P. 209-219. 7. Dalton H. The Measurement of the Inequality of Income. The Economic Journal. 1920. 30 (119). P. 348-361. 8. Atkinson A. B. On the Measurement of Inequality. Journal of Economic Theory. 1970. № 2. R. 244-263. 9. Cowell F. A. On the Structure of Additive Inequality Measures. Review of Economic Studies. 1980. № 47. P. 521-531. 10. Yitzhaki S. and Lerman R. Income Inequality Effects by Income Source: a New Approach and Applications to the United States. The Review of Income and Wealth. 1991. № 37. P. 313-329. 11. Mandybura V. O. Riven zhyttia naselennia Ukrainy ta problemy reformuvannia mekhanizmiv yoho rehuliuvannia. K. : Parlam. vyd-vo, 1998. 223 s. 12. Ponomarenko V. S., Kyzym M. O., Uzunov F. V. Riven i yakist zhyttia naselennia Ukrainy : monohrafiia. Kh. : INZhEK, 2003. 226 s. 13. Yurchyk H. M., Samoliuk N. M. Otsiniuvannia dyferentsiatsii dokhodiv naselennia Ukrainy z urakhuvanniam yikh tinovoi komponenty. Demohrafiia ta sotsialna ekonomika. 2016. № 3 (28). S. 133-145. 14. Duchynska N. I. Rozpodil dokhodiv: rynkova efektyvnist ta sotsialna spravedlyvist. Naukovyi visnyk Mizhnarodnoho humanitarnoho universytetu. Ser. Ekonomika i menedzhment. 2015. № 14. S. 254-257. 15. Semenov V. V. Ekonomikostatystychni modeli ta metody doslidzhennia sotsialnykh protsesiv: nerivnist, bidnist, poliaryzatsiia : monohrafiia: v 2 t. / vidp. red. Novikov V. M. Poltava : RVVPUSKU, 2008. T. 1. Nerivnist. 237 s. 16. Hvelesiani A. H. Otsinka struktury hroshovykh dokhodiv naselennia Ukrainy metodom dekompozytsii koefitsiienta Dzhyni. Demohrafiia ta sotsialna ekonomika. 2009. № 2. S. 153-161. 17. Yurchyk H. M., Samoliuk N. M. Teoretychni aspekty formuvannia, rozpodilu ta pererozpodilu dodanoi vartosti. Ekonomika ta suspilstvo. 2018. № 14. S. 49-59. URL: http://economyandsociety.in.ua (data zvernennia: 20.09.2020). 18. Bilan Y., Mishchuk H., Samoliuk N., Yurchyk H. Impact of income distribution on social and economic well-being of the state. Sustainability. 2020. 12(1). P. 429. DOI: https://doi.org/10.3390/su12010429. 19. Statystychni dani Derzhavnoi sluzhby statystyky Ukrainy. Vytraty na robochu sylu: statystychni zbirnyky za 2010, 2014 ta 2018 roky. URL: http://www.ukrstat.gov.ua (data zvernennia: 20.09.2020). 20. Statystychni dani Yevrostat. Struktura vytrat na robochu sylu. URL: http://epp.eurostat.ec.europa.eu (data zvernennia: 20.09.2020). 21. Humeniuk V. Ya., Samoliuk N. M. Upravlinnia vytratamy na personal : monohrafiia. Rivne: NUVHP, 2012. $158 \mathrm{~s}$.

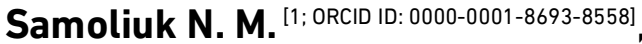
Candidate of Economics (Ph.D.), Associate Professor

${ }^{1}$ National University of Water and Environmental Engineering, Rivne

\section{FEATURES OF INCOME DISTRIBUTION OF THE SOCIAL AND LABOR SPHERE STAKEHOLDERS}

The article considers the features of the functional distribution of 
income in the European Union and Ukraine. As a result, it was found that GDRs are distributed in the EU almost proportionally between the factors «capital» and «labor» - their shares are $46.1 \%$ and $44.4 \%$, respectively. A similar trend is characteristic of Ukraine. However, the analysis showed that the share of wages in GDP by type of economic activity differs from the national average by tens of percent.

Since the dynamics of the total share of the factor «labor» does not reflect the real state of affairs in the distribution relationship, so the analysis also used the indicator «cost per employee». The results of the study confirmed that the cost of maintaining an employee in the economically developed countries is quite high. There is also a negative trend in increasing the already large gap between the average cost per employee in Ukraine and similar costs in the EU.

All costs for the maintenance of employees, according to the criterion of legal guarantee, can be divided into two groups: guaranteed costs (direct wages; payment for overtime; bonuses and irregular payments; wages in kind; social security of employees) and non-guaranteed (voluntary) payments (payment for housing; professional training; cultural and household services and other expenses). The analysis revealed that the share of legally guaranteed costs that the owner is obliged to incur for the benefit of its employees in Ukraine is quite high and has a steady upward trend. At the same time, the costs that incur on a voluntary basis and are not regulated by the government have been hardly covered in Ukraine, compared to the EU countries.

Keywords: income; value added; income distribution; factors of production; functional distribution of income; labor costs.

Самолюк Н. Н. ${ }^{[1 ;}$ ORCID ID: 0000-0001-8693-8558], к.э.н., доцент

${ }^{1}$ Национальный университет водного хозяйства и природопользования, г. Ровно

\section{ОСОБЕННОСТИ РАСПРЕДЕЛЕНИЯ ДОХОДОВ СТЕЙКХОЛДЕРОВ СОЦИАЛЬНО-ТРУДОВОЙ СФЕРЫ}

В данной статье рассмотрены особенности функционального распределения доходов в разрезе стран Европейского союза и Украины; проанализированы тенденции распределения добавленной стоимости между факторами производства по видам экономической деятельности; исследована структура доли дохода, принадлежащей фактору «труд» по критерию законодательной гарантированности или добровольности.

Ключевые слова: доходы; добавленная стоимость; распределение доходов; факторы производства; функциональное разделение доходов; расходы на рабочую силу. 